Jurnal Health Sains: p-ISSN: 2723-4339 e-ISSN: 2548-1398

Vol. 2, No. 4, April 2021

\title{
MANIFESTASI KULIT PADA DIABETES MELITUS
}

\section{Syahrizal}

Universitas Syiah Kuala, Banda Aceh, Indonesia

Email: syahrizalmedicine05@gmail.com

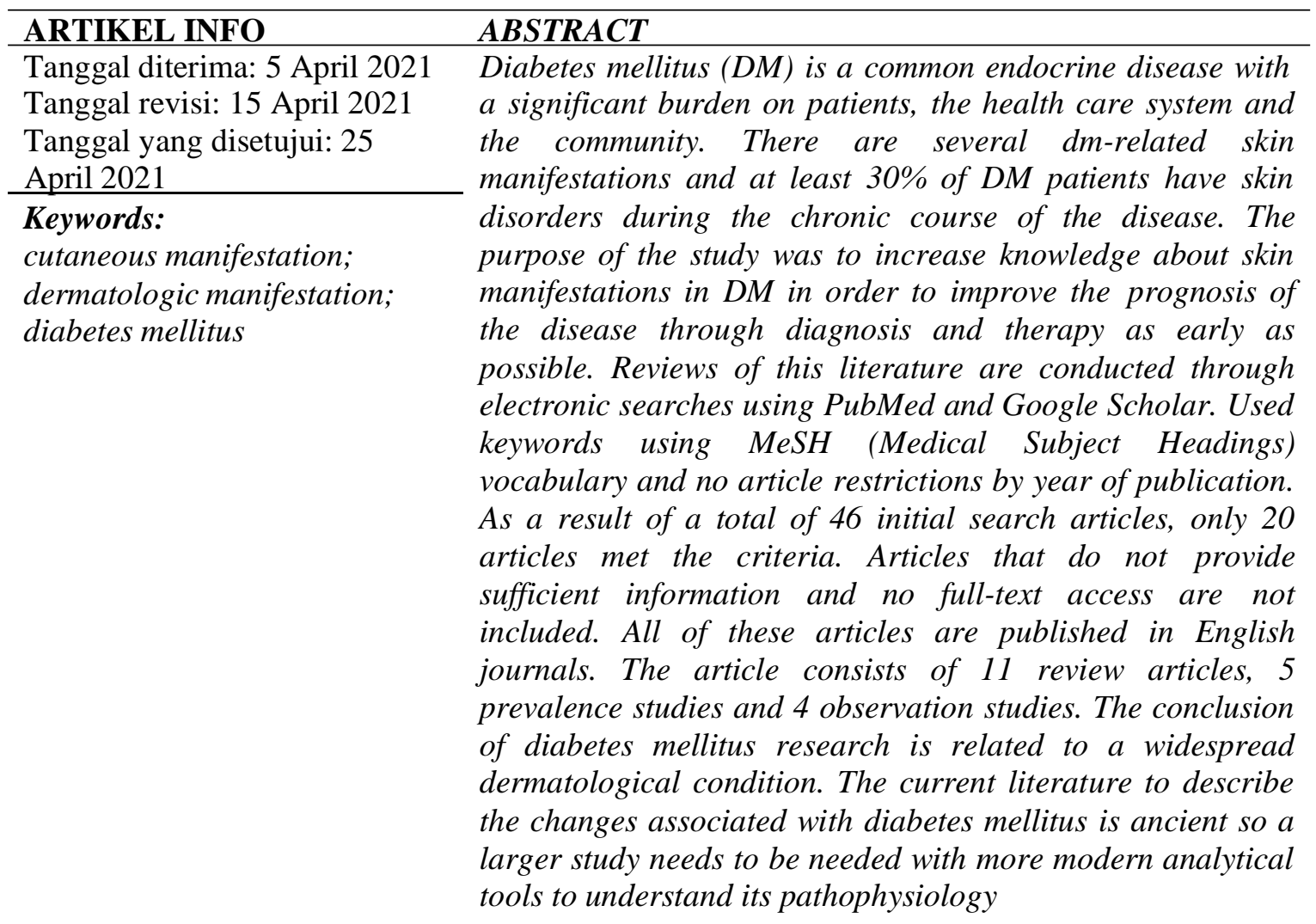

ABSTRAK

Diabetes melitus (DM) merupakan penyakit endokrin yang umum ditemui dengan beban yang signifikan pada pasien, sistem pelayanan kesehatan dan komunitas. Terdapat beberapa manifestasi kulit yang berhubungan dengan DM dan sedikitnya $30 \%$ pasien DM memiliki kelainan kulit selama perjalanan kronis penyakitnya. Tujuan penelitian untuk menambah pengetahuan tentang manifestasi kulit pada DM agar dapat meningkatkan prognosis penyakit melalui diagnosis dan terapi sedini mungkin. Tinjauan literatur ini dilakukan melalui penelusuran elektronik menggunakan PubMed dan Google Scholar. Digunakan kata kunci menggunakan kosakata MeSH (Medical Subject Headings) dan tidak terdapat pembatasan artikel berdasarkan tahun publikasi. Hasil penelitian dari total 46 artikel penelusuran awal, hanya 20 artikel yang memenuhi kriteria. Artikel yang tidak menyediakan informasi yang cukup dan tidak terdapat akses terhadap teks penuh tidak diikutsertakan. Semua artikel

$\begin{array}{ll}\text { How to cite: } & \text { Syahrizal (2021) Manifestasi Kulit Pada Diabetes Melitus. Jurnal Health Sains 2(4). } \\ & \text { http://jurnal.healthsains.co.id/index.php/jhs/article/view/143 } \\ \text { E-ISSN: } & 2723-6927 \\ \text { Published by: } & \text { Ridwan Institute }\end{array}$


ini dipublikasikan dalam jurnal bahasa Inggris. Artikel terdiri dari 11 artikel review, 5 studi prevalensi dan 4 studi observasi. Kesimpulan penelitian Diabetes melitus berhubungan dengan kondisi dermatologis yang luas. Literatur yang ada saat ini untuk menggambarkan perubahan kutaneus yang berhubungan dengan diabetes melitus ini telah

Kata Kunci:

manifestasi kulit; manifestasi dermatologis; diabetes melitus kuno sehingga perlu dibutuhkan studi yang lebih besar dengan perangkat analisis yang lebih modern untuk memahami patofisiologinya.

\section{Pendahuluan}

Diabetes Melitus (DM) merupakan salah satu penyakit penyebab utama morbiditas dan mortalitas di Indonesia. Menurut hasil Riset Kesehatan Dasar (Riskesdas) tahun 2018 secara nasional, prevalensi diabetes melitus di Indonesia adalah 2\% (Riskesdas, 2013). Pria dan wanita yang terdiagnosis diabetes pada usia 40 tahun diperkirakan mengalami penurunan harapan hidup sebesar 12 tahun untuk pria dan 14 tahun untuk wanita (Schachtel \& Kalus, 2019). Diabetes ditandai dengan keadaan defisiensi insulin relatif maupun komplit yang menyebabkan terganggunya metabolisme glukosa, lemak dan protein (Narayan et al., 2003). Diabetes didiagnosis bila kadar glukosa darah puasa melebihi $126 \mathrm{mg} / \mathrm{dL}$, kadar glukosa darah sewaktu melebihi 200 $\mathrm{mg} / \mathrm{dL}$ atau bila kadatgr $\mathrm{HbA1c}$ melebihi $6,5 \%$. Abnormalitas insulin dan peningkatan kadar glukosa darah menyebabkan gangguan metabolis, vaskular, neuropatik dan imunologik. Organ yang terkena meliputi sistem kardiovaskular, ginjal, sistem syaraf, mata dan kulit (Schachtel \& Kalus, 2019).

Banyak studi menunjukkan bahwa kontrol glikemik yang ketat dapat menurunakan penyakit mikrovaskular seperti retinopati, neuropati dan nefropati. Namun penyakit vaskular koroner yang merupakan kontributor utama dalam morbiditas dan mortalitas pasien dengan diabetes tidak mendapat keuntungan dari kontrol glikemik intensif pada pasien yang mengidap diabetes yang lama. Kontrol glikemik mungkin memberikan manfaat pada kasus DM tipe 2 yang beru terdiagnosis. Kontrol glikemik juga mungkin memberikan efek menguntungkan pada subtipe DM yang terkait dengan gangguan kulit, namun bukti ilmiah yang ada masih kurang (Holman et al., 2008; Skyler et al., 2009).

Hampir semua pasien DM memiliki temuan kutaneus terkait dengan kondisinya. Beberapa kondisi kulit yang berhubungan dengan diabetes terjadi sebagai akibat langsung perubahan metabolik terkait dengan hiperglikemia dan hiperlipidemia. Kerusakan progresif sistem vaskular, neurologis maupun imunologis juga berkontribusi secara signifikan terhadap manifestasi kulit. Mekanisme lain kondisi kulit yang terkait dengan DM masih belum diketahui (Schachtel \& Kalus, 2019).

Hiperglikemia menyebabkan glikosilasi non-enzimatik dari protein struktural dan protein regulator termasuk kolagen. Meskipun glikosilasi non enzimatik terjadi secara normal pada proses penuaan, pada DM terjadi akselerasi proses ini (Dyer et al., 1993). Hal ini menyebabkan pembentukan Advanced Glycation End Products (AGEs) yang bertanggung jawab untuk menurunkan solubilitas asam dan pencernaan enzimatik dari kolagen kulit. Kelainan seperti diabetic thick skin dan limited joint mobility (LJM) diperkirakan berasal dari terakumulasinya AGEs (Buckingham et al., 1984). Studi yang ada menunjukkan bahwa derajat kadar AGEs kutaneus berhubungan kuat dengan komplikasi retinopati, nefropati dan 
mikrovaskular lain pada DM. Terdapat peningkatan ketertarikan dalam pengukuran AGEs non invasif pada kulit dan hubungannya dengan resiko mikro- dan makrovaskular DM (Monnier et al., 1999).

Perubahan pada mekanisme imunoregulatori juga terjadi pada diabetes. Hiperglikemi dan ketoasidosis menurunkan kemampuan sel darah putih dalam kemotaksis, fagositosis dan kemampuan bakterisidal. Infeksi dahulunya menjadi penyebab utama kematian pada pasien diabetes, namun hal ini telah berubah dramatis dengan peningkatan kontrol glukosa dan penggunaan antibiotik. Meskipun demikian, beberapa keadaan infeksi seperti otitis eksterna maligna, infeksi jaringan lunak nekrotis, dan mukormikosis, terjadi lebih sering pada pasien diabetes (Joshi et al., 1999; Porte et al., 2003).

Abnormalitas metabolik seperti hiperinsulinemia pada diabetes melitus tipe 2 resisten insulin berkontribusi pada manifestasi kulit. Aksi dari insulin pada reseptor insulin-like growth factor-1 (IGF-1) tampaknya menjadi mediator terjadinya proliferasi epidermal abnormal yang menyebabkan keadaan akantosis nigrikans. Gangguan metabolisme lemak terjadi pada diabetes yang terkait dengan defisiensi insulin. Hal ini menyebabkan terjadinya hipertrigliseridemia yang bermanifestasi pada kulit sebagai xanthoma eruptif. Secara alamiah, gangguan proses metabolisme lemak juga berperan dalam vaskulopati pada DM (Schachtel \& Kalus, 2019).

Makroangiopati dan mikroangiopati berkontribusi secara signifikan terhadap komplikasi kutaneus pada diabetes. Pada pasien diabetes, terdapat peningkatan permeabilitas dinding pembuluh darah, penurunan respon vaskular terhadap inervasi simpatis dan penurunan kemampuan untuk merespon stres termal dan hipoksemia. Kombinasi dengan arteriosklerosis pembuluh darah besar, kelainan mikrovaskular ini berkontribusi terhadap pembentukan ulkus diabetikus. Sebagai tambahan, kehilangan inervasi kulit sensoris yang terjadi pada diabetes menjadi predisposisi pasien terhadap infeksi dan luka. Kehilangan jalur pensinyalan sel neuroinflamasi memainkan peranan dalam penyebab ulkus ekstremitas bawah. Pasien diabetes yang memiliki gangguan pada persepsi getaran pada ektremitas bawah memiliki peningkatan kerentanan terhadap amputasi kaki sebesar 15,5 kali lipat (Porte et al., 2003).

Tinjauan literatur ini bertujuan untuk menambah pengetahuan tentang manifestasi kulit pada DM agar dapat meningkatkan prognosis penyakit melalui diagnosis dan terapi sedini mungkin.

\section{Metode Penelitian}

Tinjauan literatur ini dilakukan melalui penelusuran elektronik menggunakan PubMed dan Google Scholar. Tidak digunakan penyaringan dalam penelusuran ini. Digunakan kata kunci menggunakan kosakata MeSH (Medical Subject Headings) yaitu manifestasi kulit, manifestasi dermatologis, manifestasi kutaneus, diabetes melitus. Tidak terdapat pembatasan artikel berdasarkan tahun publikasi.

Dari total 46 artikel penelusuran awal, hanya 20 artikel yang memenuhi kriteria. Artikel yang tidak menyediakan informasi yang cukup dan tidak terdapat akses terhadap teks penuh tidak diikutsertakan.

\section{Hasil dan Pembahasan}

Dua puluh (20) artikel memiliki kualitas yang cukup untuk diikutsertakan dalam tinjauan literatur. Semua artikel ini dipublikasikan dalam jurnal bahasa Inggris. Artikel terdiri dari 11 artikel review, 5 studi prevalensi dan 4 studi observasi. Dibawah ini dijelaskan tentang manifestasi kulit pada penderita DM.

\section{Akantosis Nigrikans}

Jurnal Health Sains, Vol 2, No 4, April 2021 


\begin{abstract}
Akantosis nigrikans merupakan manifestasi kulit diabetes yang paling mudah dan dikenali dan sering dijumpai pada populasi umum. Kebanyakan kasus sering berhubungan dengan obesitas dan resistensi insulin. Pada beberapa kasus juga teridentifikasi peningkatan produksi androgen. Akantosis nigrikans idiopatik dan yang berhubungan dengan obat serta familial merupakan penyebab tambahan (Schachtel \& Kalus, 2019). Secara umum, akantosis nigrikans dipertimbangkan sebagai indikator prognostik perkembangan diabetes tipe 2 (Stuart et al., 1998).
\end{abstract}

Akantosis nigrikans ditandai dengan penebalan kulit papilomatosa berwarna coklat hingga abu kehitaman pada area fleksural termasuk leher postero-lateral, aksila, selangkangan dan lipatan abdomen. Distribusi biasanya simetris. Kulit yang terkena memiliki tekstur seperti beludru. Pada beberaa kasus, mukosa oral, esofagus, faring, laring, konjungtiva dan anogenital dapat terlibat. Secara umum, punggung leher merupakan area yang paling sering dan berat terkena. Akrokordon dapat terbentuk superimpos pada area yang terlibat. Pada beberapa kasus, keterlibatan punggung tangan dan telapak tangan dapat terlihat dan hal ini biasanya berhubungan dengan keganasan. Pada mayoritas kasus, faktor yang paling terpenting dalam diagnosis akantosis nigrikans adalah mengenali hubungannya dengan hiperinsulinemia yang merupakan faktor risiko pada diabetes tipe 2 dan sindrom metabolic (Rosen \& Yosipovitch, 2018).

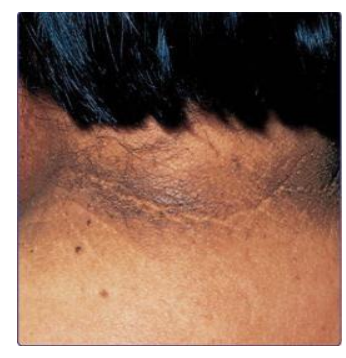

(A)

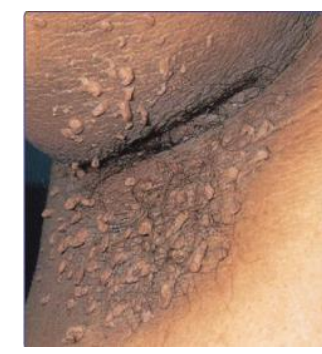

(B)

\section{Gambar 1}

(A) Akantosis Nigrikans Pada Leher. (B) Akantosis Nigrikans Pada Aksila Dengan Akrokordon Multipel

Insulin memainkan peran utama yang jelas pada akantosis nigrikans. Pada wanita dengan hiperandrogenisme dan resistensi insulin dengan akantosis nigrikans, ditemukan mutasi pada reseptor insulin ataupun pada anntibodi reseptor anti insulin. Stimulasi faktor pertumbuhan yang berlebihan pada kulit dipercaya menyebabkan proliferasi menyimpang dari keratinosit dan fibroblast $\mathrm{nm}$ yang menyebabkan gambaran klinis akantosis nigrikans. Dalam keadaan resistensi insulin dan hiperinsulinemia, akantosis nigrikans dapat terjadi akibat ikatan insulin yang berlebihan dengan reseptor IGF1 pada keratinosit dan fibroblast (Rosen \& Yosipovitch, 2018; Schwartz, 1994).

Reseptor IGF1 di ekspresikan pada keratinosit basal dan mengalami regulasi keatas pada kondisi proliferatif. Studi yang ada menunjukkan bahwa konsentrasi insulin yang tinggi menstimulasi proliferasi fibroblas melalui reseptor IGF1 secara in vitro. Keluarga reseptor tyrosin kinase lain termasuk reseptor faktor pertumbuhan epidermal dan faktor pertumbuhan fibroblast terlibat pada akantosis nigrikans. Histopatologi dari lesi klinis menunjukkan papilomatosis dan hiperkeratosis dengan akantosis minimal. Hiperpigmentasi pada lapisan basal ditemukan bervariasi dan lesi yang 
berwarna coklat paling berkaitan dengan hiperkeratosis (Torley et al., 2002).

Terapi akantosis nigrikans umumnya tidak efektif. Terapi topikal dengan kalsipotriol, asam salisilat, peeling asam glikolat, urea, retinoid topikal dan sistemik telah dilaporkan penggunaannya dengan keberhasilan yang anekdot. Laser aleksandrit denyut panjang efektif pada 1 pasien. Bila akantosis nigrikans dijumpai, terapi penyebab yang mendasari mungkin lebih menguntungkan. Perbaikan bahkan resolusi terjadi dengan penurunan berat badan pada beberapa pasien obesitas. Medikasi yang dapat memperbaiki sensitivitas insulin seperti metformin memiliki keuntungan secara teori (Rosen \& Yosipovitch, 2018).

2. Penebalan kulit diabetik (Diabetic thick skin)

Beberapa sindrom spesifik dihubungkan dengan penebalan kulit diabetes terlokalisir. Patogenesis umum yang mendasari adalah keterlibatan biokimia yang menyimpang pada kolagen dermal dan mukopolisakarida. Sindrom klinis disebabkan peningkatan deposisi dan degradasi yang tidak sesuai dari konstituen ini yang bekaitan erat dengan terbentuknya AGEs (Rosen \& Yosipovitch, 2018).

3. Limited Joint Mobility dan Sclerodermalike Syndrome

Diabetes LJM (Limited joint mobility) digambarkan sebagai penebalan dan pengetatan kulit dan jaringan ikat periartikular jari-jari tangan yang menyebabkan kehilangan mobilitas sendi yang tidak nyeri. Keterlibatan awal dari sendi interfalang distal pada jari kelima biasanya meluas secara proksimal hingga melibatkan semua jari. Sendi yang lebih besar seperti siku, lutut dan kaki mungkin dapat terkena. Meskipun demikian, sendi akrual tetap tidak terlibat karna LJM bukanlah artropati murni. Kelainan ini ditandai dengan "prayer sign" yang merupakan ketidakmampuan permukaan telapak tangan dengan sendi interfalang untuk aproksimasi ketika kedua tangan saling ditekan serta jari-jari mengalami pemisahan. (Gambar 2) (Rosen \& Yosipovitch, 2018). Selain kontraktur sendi, kulit juga tampak menebal, mengkilat dan licin dengan adanya kehilangan adneksa jaringan kulit yang menyerupai perubahan kulit pada scleroderma (Yosipovitch et al., 1998).

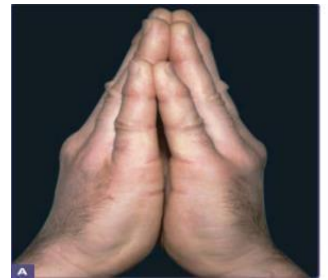

(A)

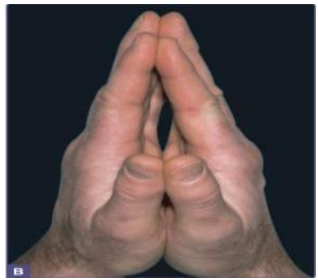

(B)
Gambar 2

Mobilitas Sendi Terbatas Pada Seorang Pria Berusia 31 Tahun Dengan DM Tipe 1. (A) Sisi Ulnar; Tampak Hanya Ujung Jari Yang Dapat Aproksimasi. (B) Sisi Radial; Keterbatasan Untuk Menyatukan Kedua Telapak Tangan.

Pada pasien dengan DM tipe 1, 30$50 \%$ mengalami LJM dan hal ini juga umum ditemukan pada DM tipe 2. LJM dihubungkan dengan peningkatan durasi diabetes dan kontrol glukosa darah yang buruk. Pada satu studi prospektif longitudinal menunjukkan bahwa terjadi peningkatan risiko LJM sebesar 2,5 kali setiap terjadi peningkatan unit HbAlc. sebagai tambahan, LJM mungkin muncul berkorelasi dengan adanya penyakit mikrovaskular (Rosen \& Yosipovitch, 2018).

Hal yang paling penting adalah, bukti yang ada menunjukkan bahwa terapi insulin yang intens merupakan pencegahan 
utama dan menjadi terapi yang memungkinkan untuk LJM dan sindrom menyerupai skleroderma (sclerodermalike syndrome). Kontrol glikemik jangka panjang menyebabkan penurunan AGEs pada kulit serta kontrol glikemik yang ketat berhubungan dengan onset yang lambat dan keparahan dari LJM. Penatalaksanaan diabetes yang baik dapat menurunkan frekuensi LJM sebesar 4 kali lipat. Terapi LJM sulit dan berfokus pada kontrol glukosa darah yang ketat serta terapi fisik untuk menjaga ruang gerak aktif (Lindsay et al., 2005; Rosen \& Yosipovitch, 2018).

Meskipun perubahan kulit yang menyerupai skleroderma dapat terjadi sendiri, namun kondisi ini sering terjadi bersamaan dengan LJM pada pasien diabetes. Kondisi ini tidak dihubungkan dengan sklerosis sistemik namun berkorelasi dengan durasi diabetes dan keparahan kontraktur sendi dan retinopati. Pilihan terapetik pada kasus ini sangat terbatas. Laporan observasional menyarankan bahwa kontrol gula darah yang ketat dapat memperbaiki keadaan (Rho et al., 1998; Rosen \& Yosipovitch, 2018).

4. Skleredema Diabetikorum (Scleredema Diabetivorum)

Skleredema diabetes muncul sebagai indurasi simetris dan penebalan kulit pada punggung atas dan leher dengan onset bebas nyeri yang tersembunyi. Penyebaran pada wajah, bahu dan batang tubuh bagian anterior dapat terjadi. Tampilan kulit tampak seperti kayu, nonpitting dan peau d'orange. Perubahan yang sama juga terjadi pada skleredema paska infeksi, biasanya berhubungan dengan faringitis streptokokal (Schachtel \& Kalus, 2019).

Skleredema diabetikorum mengenai $2,5-14 \%$ pasien dengan diabetes.
Skleredema diabetikorum merupakan penyakit akibat diabetes jangka lama yang berhubungan dengan obesitas dan kebanyakan adalah pasien DM tipe 2 . Kelainan ini tidak pernah dilaporkan pada anak-anak (Rosen \& Yosipovitch, 2018).

$$
\text { Patogenesis }
$$

skleredema

diabetikorum diasumsikan sebagai akibat produksi molekul matriks ekstraseluler yang tidak terkontrol oleh fibroblast, menyebabkan penebalan bundel kolagen dan peningkatan deposisi dari glikosaminoglikans (terutama asam hialuraonat). Studi dengan analisis fibroblast in vitro pada kulit yang terlibat menunjukkan peningkatan sintesis glikosaminoglikan dan kolagen tipe 1 yang bervariasi (Martin et al., 2011).

Pasien dengan skleredema diabetikorum dapat mengalami penurunan sensasi nyeri dan tekanan ringan pada area yang terkena serta mengalami kesulitan gerak pada ekstremitas atas dan area leher. Pada kasus ekstrim dapat menyebabkan kehilangan ruang gerak secara penuh. Namun tidak seperti pada LJM dan scleroderma-like syndrome, skleredema tidak berkorelasi dengan adanya gangguan vaskular seperti retinopati, nefropati, neuropati maupun penyakit vaskular umum lainnya. Meskipun demikian, belum terdapat studi prospektif berskala besar pada kasus ini (Rosen \& Yosipovitch, 2018).

Kebanyakan pasien dengan skleredema diabetikorum menjadi dependen insulin sehingga sulit untuk ditangani dan memiliki komplikasi diabetes yang multipel. Terapi skleredema diabetikorum biasanya tidak berhasil. Laporan kasus yang telah ada menjelaskan penatalaksanaan dengan radioterapi, metotreksat dosis rendah, psoralen dan UVA (PUVA), fotoporesis ekstrakorporeal, faktor XIII dan prostaglandin E1. Penurunan berat badan 
dan terapi fisik untuk mempertahankan ruang gerak mungkin dapat membantu (Ferreli et al., 2017).

\section{Erupsi Xanthoma (Eruptive Xanthomas)}

Erupsi xanthoma digambarkan secara klinis sebagai papul kuning kemerahan berukuran $1 \mathrm{~mm}$ hingga $4 \mathrm{~mm}$ pada daerah bokong dan permukaan ekstensor ekstremitas. Lesi yang terjadi berkumpul dan dapat bersatu membentuk plak seiring dengan waktu. Meskipun erupsi xanthoma secara umum asimptomatis, sering dijumpai hipertrigliseridemia berat (>1000 mgdL) yang mendasari serta potensi diabetes yang tidak terdiagnosis. Diabetes yang tidak terdiagnosis umumnya menyebabkan hipertrigliseridemia masif. Studi histologis dan biokimia menunjukkan bahwa lipoprotein (khususnya kilomikron) pada darah pindah menuju dinding pembuluh darah kulit dan berakumulasi pada makrofag di dermis. Awalnya trigliserida predominan pada lesi kulit, karena trigliserida lebih mudah termobilisasi dibanding dengan kolesterol, namun lesi berkembang secara progresif mengandung lebih banyak kolesterol ketika mengalami penyembuhan (Vergès, 2015).

Kadar trigliserida diatas 4000 $\mathrm{mg} / \mathrm{dL}$ dapat menyebabkan lipemia retinalis. Pada pemeriksaan funduskopik, lipemia retinalis muncul sebagai arteriol dan venul retinal berwarna pink pucat hingga putih. Hipertrigliseridemia berat juga dapat muncul dengan gambaran klinis nyeri abdomen, hepatosplenomegali, pankreatitis atarupun dispnea yang disebabkan penurunan kapasitas difusi paru-paru dan afinitas hemoglobin yang abnormal. Terapi hipertrigliseridemia termasuk modifikasi gaya hidup dan kontrol diabetes yang mendasari. Erupsi xanthoma biasanya memiliki respon cepat dan dapat mengalami resolusi komplit dalam 6-8 minggu (Schachtel \& Kalus, 2019).

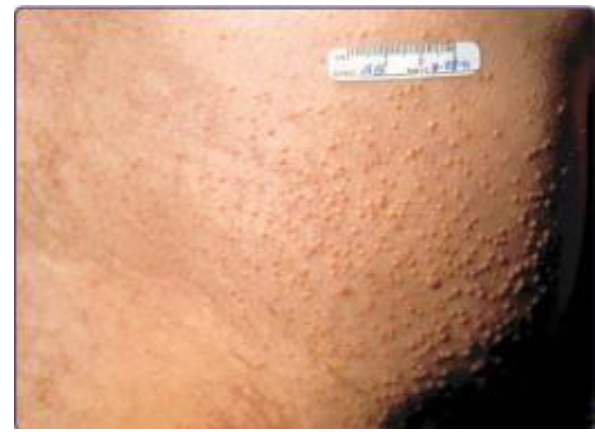

Gambar 3

Erupsi Xanthoma Pada Pasien Pria

Dengan DM Tipe 2. Tampak Papul Dan Plak Berwarna Kuning-Orange

6. Infeksi Kulit

Pada pasien diabetes, terdapat bukti yang tidak kuat bahwa terjadi peningkatan kerentanan terhadap infeksi secara umum, namun beberapa infeksi kulit memang terjadi lebih sering dan dengan tingkat keparahan yang lebih serta komplikasi yang lebih parah pada pasien DM. Hal ini sesuai dengan studi oleh Joshi dkk (Joshi et al., 1999).

Terdapat penelitian yang luas terhadap patogenesis disfungsi imun pada diabetes. Meskipun demikian, beberapa studi tidak melakukan deteksi gangguan pada tingkat seluler, studi lain menunjukkan bahwa kemotaksis leukosit, adherensi dan fagositosis mengalami gangguan pada pasien diabetes, khususnya pada keadaan hiperglikemia dan diabetik asidosis. Studi lebih lanjut menunjukkan bahwa fungsi sel-T kulit dan respon terhadap antigen juga mengalami penurunan pada diabetes. Tabel berikut menunjukkan beberapa infeksi kulit yang sering terjadi dan beberapa lebih berat pada pasien DM. 
Tabel 1

Infeksi Yang Lebih Sering Dan Atau Lebih Berat Pada Pasien DM

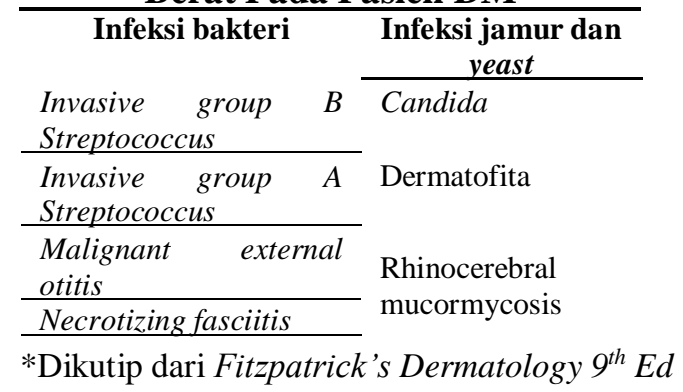

7. Ulkus Diabetik

Ulkus kaki merupakan masalah yang signifikan dan terjadi pada $15-25 \%$ pasien diabetes. Pasien dengan diabetes memiliki perkiraan peningkatan risiko mengalami amputasi ekstremitas bawah sebesar 10-30 kali lebih besar dibandingkan dengan populasi umum. Ulkus ekstremitas bawah tercatat pada $25 \%$ pasien diabetes rawat inap di rumah sakit dan menjadi penyebab proksimal amputasi dari $84 \%$ pasien. Pada pasien diabetes dengan ulkus kaki, 14-24\% akan mengalami amputasi(Schachtel \& Kalus, 2019).

Pembentukan kalus mendahului nekrosis dan pemecahan jaringan pada area penonjolan tulang kaki, biasanya pada ibu jari dan telapak kaki dan atau sendi metakarpofalang kedua. Ulkus dikelilingi oleh cincin kalus dan dapat meluas pada sendi dan tulang yang mendasari. Komplikasi ulkus adalah infeksi jaringan lunak dan osteomyelitis (Singh et al., 2005).

Banyak faktor yang terlibat dalam patogenesis ulkus diabetik. Neuropati perifer, tekanan dan trauma diperkirakan memainkan peranan pada perkembangan ulkus diabetik. Neuropati (berhubungan dengan hiperglikemia tidak terkontrol) merupakan prediktor utama dalam ulkus diabetes. Pasien dengan diabetes juga mengalami kehilangan syaraf sensori kulit.
Hal ini menyebabkan penurunan jalur sinya neuroinflamatori melalui neuropeptida pada keratinosit, fibroblast, sel endotel dan sel inflamatori yang dapat mempengaruhi penyembuhan luka (Jeffcoate \& Harding, 2003; Lobmann et al., 2005).

Dalam sebuah studi pada 314 pasien diabetes dengan ulkus, ketidaksesuaian pada sepatu dan kaus kaki menjadi penyebab utama terjadinya ulkus kaki. Pembentukan kalus merupakan tanda friksi berlebihan dan sering mendahului ulkus kaki (Apelqvist et al., 1990). ketika ulkus berkembang, penyakit vaskular perifer dan gangguan penyembuhan luka intrinsik berkontribusi terhadap outcome yang jelek. Faktor yang telah diketahui berhubungan dengan ulkus kaki pada diabetes adalah ulkus kaki sebelumnya, amputasi ekstremitas bawah sebelumnya, lama durasi diabetes (>10 tahun), gangguan akuitas visual, onikomikosis dan kontrol glikemik yang buruk (Schachtel \& Kalus, 2019).

Terapi ulkus diabetes membutuhkan modifikasi faktor yang berkontribusi terhadap pembentukan ulkus termasuk dermatitis statis, edema kaki dan infeksi kulit. Terapi standar dari ulkus diabetes neuropati termasuk debridemen, menurunkan sumber tekanan (off-loading), perawatan lukan dan dressing pelindung. Terdapat peningkatan ketertarikan dalam mengembangkan terapi adjuvan untuk ulkus diabetes termasuk pemberian faktor pertumbuhan dan produk pengganti kulit, namun data yang ada tidak mendukung penggunaannya sebagai pengganti perawatan luka standard. Faktor pertumbuhan derivat platelet rekombinan sebagai terapi topikal ulkus diabetes kaki menunjukkan keuntungan bila digunakan dengan off-loading yang adekuat, debridemen dan kontrol infeksi. 
Pencegahan ulkus menjadi intervensi yang paling penting pada pasien diabetes yang dapat diberikan oleh dokter dan penyedia pelayanan kesehatan lain. Kontrol glikemik yang optimal merupakan pendukung yang baik untuk mencegah neuropati yang sangat berkaitan dengan ulkus kaki. Pemeriksaan kaki harus dilakukan setiap kunjungan pasien diabetes. Bila tinea pedis ditemukan, haruslah segera ditangani untuk mencegah gangguan sawar kulit.

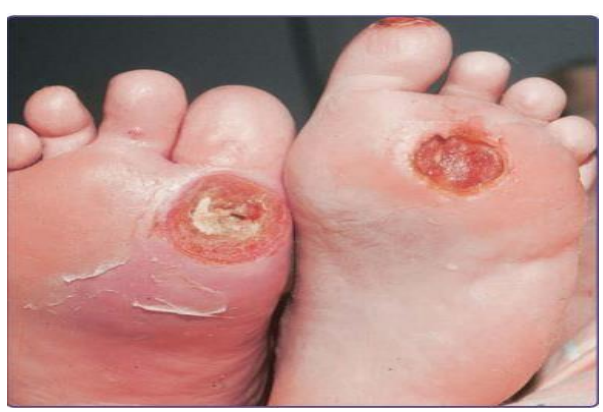

Gambar 4

Ulkus Diabetik Pada Kaki Pria Berusia 56

Tahun Dengan DM Yang Berdurasi 20

Tahun. Terdapat Neuropati Sensori Dan

Penyakit Vaskular Perifer Yang Signifikan

8. Nekrobiosis Lipoidika (Necrobiosis Lipoidica)

Nekrobiosis Lipoidika (NL), kelainan ini dinamai sesuai dengan temuan histologis yang khas pada pasien diabetes. Secara klasik, NL muncul sebagai 1 atau beberapa plak kuning kecoklatan yang berbatas tegas. Lesi ini memiliki tepi ireguler yang violaseus yang dapat meninggi ataupun mengalami indurasi. Awalnya NL hadir sebagai papul dan nodul berwarna merah kecoklatan yang menyerupai sarkoid ataupun granuloma anulare. Seiring dengan waktu, lesi menjadi lebih datar dan bagian tengah berwarna kuning atau orange menjadi atrofik dan umumnya tampak telangiektasis, menjadi bentuk khas "glazed-porcelain". Daerah predileksinya selain dari tulang kering, adalah pergelangan kaki, betis, paha dan kaki. $15 \%$ kasus lesi ditemukan pada ekstremitas atas dan pada batang tubuh namun lebih cenderung bentuk papulonodular. Nyeri dan pruritus pernah dilaporkan, namun demikian kebanyakan lesi asimptomatis dan anestesi pada plak dapat terjadi.

Patogenesis kelainan ini masih belum jelas. Derajat hiperglikemia dan kontrol diabetes tampaknya tidak berkorelasi dengan kehadiran NL. Teori yang ada menhubungkannya terjadinya NL dengan mikroangiopati (Reid et al., 2013). Remisi spontan dapat terjadi pada kurang dari $20 \%$ kasus. Plak yang ada cenderung menjadi stabil seiring dengan waktu dan pembentukan lesi baru tidak terjadi. Meskipun demikian, kemungkinan untuk ulserasi, remisi spontan yang tidak terjadi serta keluhan kostmetik sering menjadi alasan pasien mencari terapi. Ulserasi menjadi komplikasi paling serius yang terjadi pada sekitar $13-35 \%$ kasus lesi pada kaki. Pada sedikit kasus, dilaporkan adanya karsinoma sel skuamos yang muncul dari lesi ulseratif kronis NL.
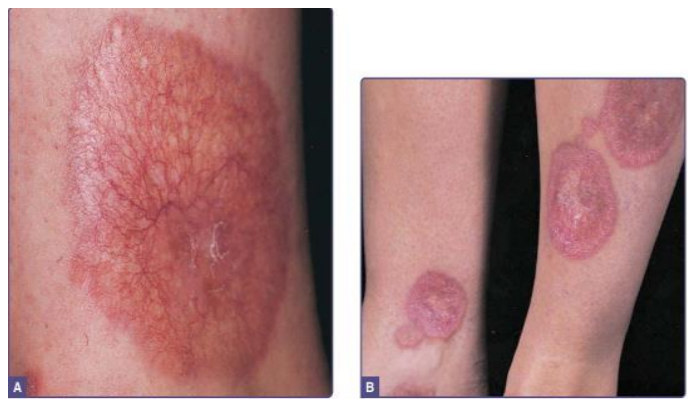

Nekrobiosis Lipoidica. (A) Tampak Plak Orange Tunggal Dengan Atrofi Dan Telangiektasis Pada Tungkai Bawah Pasien DM; Area Berkrusta Menandai Adanya Ulserasi Awal. (B) Lesi Yang Lebih Lama Tampak Adanya Atrofi Sentral Baik Pada Dermis Dan Epidermis

Terapi NL sangat mengecewakan. Laporan kasus dan uji klinis tidak terkontrol kecil menjadi dasar pilihan 
terapi. Aplikasi awal dari glukokortikoid topikal poten dapat memperlama progres penyakit. Perbaikan juga terlihat dengan penggunaan injeksi glukokortikoid intralesi pada pinggir aktif, namun resiko ulserasi melalui modalitas terapi ini harus dipertimbangkan. Beberapa laporan kasus dan laporan serial 1 dari 6 pasien menunjukkan keuntungan dengan glukokortikoid sistemik jangka pendek. Aspirin dan dipyridamol memberikan hasil yang bervariasi. Laporan anekdot yang ada mendukung penggunaan penghambat tumor nekrosis faktor- $\alpha$, retinoid topikal dan topikal PUVA. Terapi dengan ester asam fumarat pada 18 pasien dilaporkan terjadi perbaikan lesi secara klinis dan histologis (Reid et al., 2013).

9. Granuloma Anulare

Korelasi antara granuloma anulare (GA) dengan diabetes lebih rendah dibandingkan dengan NL. Dabski dan Winklemann menemukan diabetes pada 9,7\% pasien GA terlokalisir dan $21 \%$ pasien dengan GA generalisata. Studi kontrol kasus retrospektif kecil menunjukkan terjadinya peningkatan prevalensi diabetes pada pasien GA sebesar $18 \%$ dibandingkan dengan prevalensi pada kontrol dengan usia yang sama. Patogenesis kelainan ini pada DM tidak jelas.

\section{Dermopati diabetik (Diabetic Dermopathy)}

Lesi kulit atrofi pada ekstremitas bawah ataupun berupa bercak mengkilat yang pertama kali diajukan sebagai penanda kutaneus pada diabetes pada tahun 1964. Setelah itu Binkley memberikan istilah diabetic dermopathy untuk menghubungkan perubahan patologis dengan retinopati, nefropati dan neuropati. Dermopati diabetik digambarkan dengan lesi makula atrofi kecil $(<1 \mathrm{~cm})$ berwarna pink kecoklatan, menyerupai jaringan parut pada area pretibial. Lesi bersifat asimptomatis dan menyembuh dalam 1-2 tahun dengan sedikit atrofi residual ataupun hipopigmentasi. Gambaran lesi yang baru memberikan tampilan pigmentasi dan atrofi yang persisten (Schachtel \& Kalus, 2019).

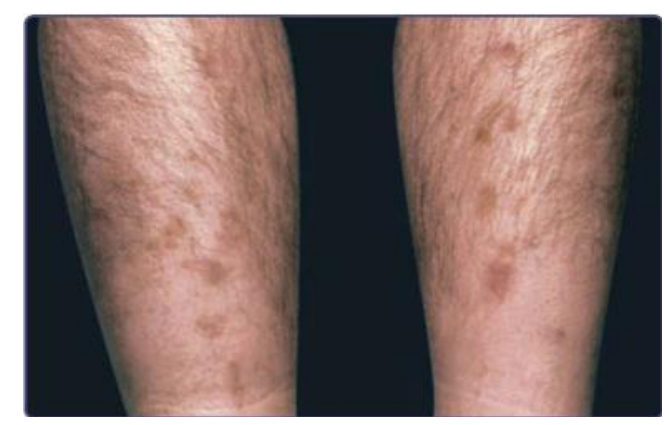

Gambar 6

Dermopati Diabetik Dengan Makula Hiperpigmentasi Pada Tungkai Bawah Anterior

Terdapat hubungan yang mungkin terjadi antara dermopati diabetik dengan komplikasi diabetes yang lebih serius. Dalam sebuah studi pada 173 pasien diabetes, insidensi bercak mengkilat berkorelasi dengan durasi diabetes dan kehadiran retinopati, nefropati dan neuropati. Meskipun demikian kelainan ini tidak berkorelasi dengan obesitas maupun hipertensi pada pasien diabetes (Shemer Avner et al., 1998).

Terdapat kontroversi mengenai etiologi kelainan ini, spesifitasnya untuk diabetes dan hubungannya dengan komplikasi mikroangiopati lain dari diabetes. Dermopati diabetik lebih sering terjadi pada pasien dengan durasi diabetes yang lama dan lebih sering ditemukan pada pria. Lesi cenderung berhubungan dengan trauma yang mendahului. Tidak diperlukan terapi untuk lesi atrofik tibial ini. Kelainan ini juga cenderung asimptomatis dan sering tidak 
berhubungan secara langsung dengan peningkatan morbiditas (Schachtel \& Kalus, 2019).

11.Kelainan perforasi didapat (Acquired Perforating Disorders)

Kelainan perforasi didapat terdiri dari grup kelainan yang saling tumpang tindih yang ditandai dengan eliminasi transepidermal atau gangguan konstituen dermal. Yang termasuk dalam grup ini adalah penyakit Kyrle, kolagenosis perforasi reaktif, folikulitis perforasi dan elastosis perforans serpiginosa ( $\mathrm{Ra}$ pini et al., 1989).

Secara klinis lesi muncul sebagai papul keratotik yang gatal terutama pada permukaan ekstensor dari ekstremitas. Papul dan nodul dengan komponen perforasi juga dapat terjadi pada batang tubuh dan wajah. Kebanyakan berbentuk folikular dan berisi sumbatan keratotik sentral yang prominen. Papul dapat berkelompok atau menyatu membentuk plak verukosa. Terapi kelainan ini biasanya tidak berhasil sepenuhnya. Asam retinoat, glukokortikoid topikal dan PUVA hanya memberikan kesuksesan yang parsial.

12.Bula Diabetikorum

(Bullosis

\section{Diabeticorum)}

Pembentukan bula yang spontan dan banyak pada ekstremitas bawah tanpa penyebab lain merupakan karakteristik manifestasi diabetes kulit yang jarang. Bula diabetikorum ditandai dengan bula pada ekstremitas bawah, biasanya pada ibu jari, kaki dan tulang kering yang berasal dari kulit normal. Umumnya ekstremitas atas bagian distal juga terlibat. Bula biasanya tidak nyeri dan tidak gatal. Penyembuhan terjadi dalam 2-5 minggu dan jarang menyebabkan terbentuknya jaringan parut. Kondisi ini dapat terjadi berulang dalam beberapa tahun.
Studi pada individu yang terkena setelah mengeksklusikan penyakit bula lainnya menunjukkan tidak adanya kelainan dalam metabolisme porfirin. Pada pemeriksaan histologis bula menunjukkan pemisahan pada tingkat yang tidak konsisten dan bervariasi pada intraepidermal hingga subepidermal. Tidak terdapat kelainan imunopatologis yang teramati (Toonstra, 1985).

Patogenesis bula diabetik ini tidak diketahui. Pasien dengan bula diabetikorum tidak memiliki riwayat trauma maupun infeksi sebelumnya. Meskipun demikian, riwayat trauma yang mendasari tidak dihilangkan karena kemungkinan temuan ini mengarahkan pada peranan dari meningkatnya fragilitas kulit pada bula diabetik. Bula diabetikorum bersifat ringan tanpa keterlibatan area permukaan tubuh yang lebih luas. Satu-satunya komplikasi serius yang dapat terjadi adalah infeksi sekunder yang dapat diatasi dengan kultur dan pemberian antibiotik yang sesuai. Selain itu terapi bersifat suportif.

\section{Kesimpulan}

Diabetes melitus berhubungan dengan kondisi dermatologis yang luas. Literatur yang ada saat ini untuk menggambarkan perubahan kutaneus yang berhubungan dengan diabetes melitus ini telah kuno sehingga perlu dibutuhkan studi yang lebih besar dengann perangkat analisis yang lebih modern untuk memahami patofisiologi yang mendasari serta memahami terapi spesifik kelainan ini.

\section{BIBLIOGRAFI}

Apelqvist, J., Larsson, J., \& Agardh, C.-D. (1990). The Influence Of External Precipitating Factors And Peripheral Neuropathy On The Development And Outcome Of Diabetic Foot Ulcers. 
Journal Of Diabetic Complications, 4(1), 21-25. Google Scholar

Buckingham, B. A., Uitto, J., Sandborg, C., Keens, T., Roe, T., Costin, G., Kaufman, F., Bernstein, B., Landing, B., \& Castellano, A. (1984). SclerodermaLike Changes In Insulin-Dependent Diabetes Mellitus: Clinical And Biochemical Studies. Diabetes Care, 7(2), 163-169. Google Scholar

Dyer, D. G., Dunn, J. A., Thorpe, S. R., Bailie, K. E., Lyons, T. J., Mccance, D. R., \& Baynes, J. W. (1993). Accumulation Of Maillard Reaction Products In Skin Collagen In Diabetes And Aging. The Journal Of Clinical Investigation, 91(6), 2463-2469. Google Scholar

Ferreli, C., Gasparini, G., Parodi, A., Cozzani, E., Rongioletti, F., \& Atzori, L. (2017). Cutaneous Manifestations Of Scleroderma And Scleroderma-Like Disorders: A Comprehensive Review. Clinical Reviews In Allergy \& Immunology, 53(3), 306-336. Google Scholar

Holman, R. R., Paul, S. K., Bethel, M. A., Matthews, D. R., \& Neil, H. A. W. (2008). 10-Year Follow-Up Of Intensive Glucose Control In Type 2 Diabetes. New England Journal Of Medicine, 359(15), 1577-1589. Google Scholar

Jeffcoate, W. J., \& Harding, K. G. (2003). Diabetic Foot Ulcers. The Lancet, 361(9368), 1545-1551. Google Scholar

Joshi, N., Caputo, G. M., Weitekamp, M. R., \& Karchmer, A. W. (1999). Infections In Patients With Diabetes Mellitus. New England Journal Of Medicine, 341(25), 1906-1912. Google Scholar

Lindsay, J. R., Kennedy, L., Atkinson, A. B., Bell, P. M., Carson, D. J., Mccance, D. R., \& Hunter, S. J. (2005). Reduced Prevalence Of Limited Joint Mobility In Type 1 Diabetes In A Uk Clinic
Population Over A 20-Year Period. Diabetes Care, 28(3), 658-661. Google Scholar

Lobmann, R., Schultz, G., \& Lehnert, H. (2005). Proteases And The Diabetic Foot Syndrome: Mechanisms And Therapeutic Implications. Diabetes Care, 28(2), 461-471. Google Scholar

Martin, C., Requena, L., Manrique, K., Manzarbeitia, F. D., \& Rovira, A. (2011). Scleredema Diabeticorum In A Patient With Type 2 Diabetes Mellitus. Case Reports In Endocrinology, 2011. Google Scholar

Monnier, V. M., Bautista, O., Kenny, D., Sell, D. R., Fogarty, J., Dahms, W., Cleary, P. A., Lachin, J., \& Genuth, S. (1999). Skin Collagen Glycation, Glycoxidation, And Crosslinking Are Lower In Subjects With Long-Term Intensive Versus Conventional Therapy Of Type 1 Diabetes: Relevance Of Glycated Collagen Products Versus Hbalc As Markers Of Diabetic Complications. Dect Skin Collagen Ancillary Study Group. Diabetes Control And Complications Trial. Diabetes, 48(4), 870-880. Google Scholar

Narayan, K. M. V., Boyle, J. P., Thompson, T. J., Sorensen, S. W., \& Williamson, D. F. (2003). Lifetime Risk For Diabetes Mellitus In The United States. Jama, 290(14), 1884-1890. Google Scholar

Porte, D., Sherwin, R. S., Baron, A., Ellenberg, M., \& Rifkin, H. (2003). Ellenberg And Rifkin's Diabetes Mellitus. Mcgraw-Hill, Health Professions Division. Google Scholar

Rapini, R. P., Hebert, A. A., \& Drucker, C. R. (1989). Acquired Perforating Dermatosis: Evidence For Combined Transepidermal Elimination Of Both Collagen And Elastic Fibers. Archives Of Dermatology, 125(8), 1074-1078. Google Scholar 
Reid, S. D., Ladizinski, B., Lee, K., Baibergenova, A., \& Alavi, A. (2013). Update On Necrobiosis Lipoidica: A Review Of Etiology, Diagnosis, And Treatment Options. Journal of The American Academy of Dermatology, 69(5), 783-791. Google Scholar

Rho, Y. W., Suhr, K. B., Lee, J. H., \& Park, J. K. (1998). A Clinical Observation Of Scleredema Adultorum And Its Relationship To Diabetes. The Journal Of Dermatology, 25(2), 103-107. Google Scholar

Riskesdas. (2013). Riskesdas 2013. In Jakarta Kementeri Kesehat Ri (Vol. 6). Google Scholar

Rosen, J., \& Yosipovitch, G. (2018). Skin Manifestations Of Diabetes Mellitus. Endotext [Internet]. Google Scholar

Schwartz, R. A. (1994). Acanthosis Nigricans. Journal of The American Academy Of Dermatology, 31(1), 1-19. Google Scholar

Shemer Avner, M. D., Bergman Reuven, M. D., Linn Drph, Shai, M. D., Kantor Yoram, M. D., \& Friedman - Birnbaum Rachel, M. D. (1998). Diabetic Dermopathy And Internal Complications In Diabetes Mellitus. International Journal of Dermatology, 37(2), 113-115. Google Scholar

Singh, N., Armstrong, D. G., \& Lipsky, B. A. (2005). Preventing Foot Ulcers In Patients With Diabetes. Jama, 293(2), 217-228. Google Scholar

Skyler, J. S., Bergenstal, R., Bonow, R. O., Buse, J., Deedwania, P., Gale, E. A. M., Howard, B. V, Kirkman, M. S., Kosiborod, M., \& Reaven, P. (2009). Intensive Glycemic Control And The Prevention Of Cardiovascular Events: Implications Of The Accord, Advance, And Va Diabetes Trials: A Position
Statement Of The American Diabetes Association And A Scientific Statement Of The American College Of Cardiology Foundation And The American Heart Association. Journal of The American College Of Cardiology, 53(3), 298-304. Google Scholar

Stuart, C. A., Gilkison, C. R., Smith, M. M., Bosma, A. M., Keenan, B. S., \& Nagamani, M. (1998). Acanthosis Nigricans As A Risk Factor For NonInsulin Dependent Diabetes Mellitus. Clinical Pediatrics, 37(2), 73-79. Google Scholar

Toonstra, J. (1985). Bullosis Diabeticorum: Report Of A Case With A Review Of The Literature. Journal of The American Academy of Dermatology, 13(5), 799-805. Google Scholar

Torley, D., Bellus, G. A., \& Munro, C. S. (2002). Genes, Growth Factors And Acanthosis Nigricans. British Journal Of Dermatology, 147(6), 1096-1101. Google Scholar

Vergès, B. (2015). Pathophysiology Of Diabetic Dyslipidaemia: Where Are We? Diabetologia, 58(5), 886-899. Google Scholar

Yosipovitch, G., Hodak, E., Vardi, P., Shraga, I., Karp, M., Sprecher, E., \& David, M. (1998). The Prevalence Of Cutaneous Manifestations In Iddm Patients And Their Association With Diabetes Risk Factors And Microvascular Complications. Diabetes Care, 21(4), 506-509. Google Scholar

\section{Copyright holder:}


Syahrizal (2021)

First publication right:

Jurnal Health Sains

This article is licensed under:

(c) (7) (2) 